\title{
PERAN KEARIFAN LOKAL BAHUMA BATAHUTN TERHADAP KONDISI LINGKUNGAN MASYARAKAT SUKU DAYAK
}

\section{The Role of Bahuma Batahutn Local Wisdom to Environmental Conditions of Dayak Tribe}

\author{
${ }^{1 \star}$ Rida Respati, ${ }^{2}$ Muh. Azhari, \& ${ }^{2}$ Sari Marlina \\ ${ }^{1}$ Civil Engineering Study Program, Universitas Muhammadiyah Palangkaraya, RTA Milono St. Km.1,5 \\ Palangka Raya, Indonesia \\ Environmental Engineering Study Program, Universitas Muhammadiyah Palangkaraya, RTA Milono St. Km.1,5 \\ Palangka Raya, Indonesia \\ *e-mail : rida respati@yahoo.com
}

\begin{abstract}
ABSTRAK
Lingkungan yang terus mengalami penurunan kualitas yang disebabkan oleh kegiatan manusia dalam mememenuhi kebutuhan hidupnya seperti pemenuhan akan sandang pangan dan papan mengharuskan manusia harus mengorbankan apa yang ada di sekitarnya untuk hal tersebut. Peran dari pemerintah dan masyarakat sangat penting dalam menjaga kelestarian lingkungan. Misalnya dengan mengoptimalkan peranan kearifan lokal yang dimiliki masyarakat seperti Bahuma Batahutn. Bahuma Batahutn merupakan salah satu cara pengelolaan lingkungan dengan bijak, yang dimiliki oleh masyarakat Suku Dayak. Jenis penelitian ini merupakan jenis penelitian kualitatif dengan menggunakan metode etnografi dan data penelitian diperoleh dengan menggunakan teknik pengumpulan data berupa kajian literatur, observasi, dan wawancara terkait kearifan lokal tersebut.
\end{abstract}

Kata kunci: Kearifan Lokal, Suku Dayak, Lingkungan

\begin{abstract}
The environment that continues to experience quality degradation caused by human activities in fulfilling the necessities of life such as the fulfillment of food and board clothing requires that human beings have to sacrifice what is around it for that matter. The role of government and society is very important in maintaining environmental sustainability. For example by optimizing the role of local wisdom owned by the public like Bahuma Batahutn. Bahuma Batahutn is one way of environmental management wisely, owned by the Dayak people. This type of research is a type of qualitative research using ethnographic methods and research data obtained by using data collection techniques in the form of literature review, observation, and interviews related to local wisdom.
\end{abstract}

Keywords: Local Wisdom, Dayak Tribe, Environment

\section{PENDAHULUAN}

Majunya peradapan manusia yang ditandai dengan laju modernisasi menyebabkan banyaknya terjadi perubahan bagi rona lingkungan sekitar. Hal tersebut mengharuskan adanya bentuk perhatian yang sungguh-sunguh untuk mempertahankan kualitas lingkungan beserta penyusunnya.

Penyusun lingkungan baik komponen abiotik dan biotik harus dalam kondisi baik dan terjaga. Sehingga kualitas lingkungan akan mampu mendukung kehidupan makhluk hidup. Pola pikir manusia akan menentukan kualitas lingkungan. Karena manusia merupakan faktor penting. Antroposentrisme menjadi momok yang dianggap kurang aik jika manusia tidak memikirkan keberlanjutan lingkungan untuk generasi yang akan datang. Manusia dapat membangun dan dapat juga merusak lingkungan sekitar. Untuk itu perlu adanya kesadaran dalam menjaga lingkungan. Sehingga permasalahan lingkungan 
dapat ditekan dan tentunya dapat menekan biaya, tenaga dan waktu.

Permasalahan segolongan manusia yang kurang sadar akan arti penting lingkungan menimbulkan banyak permasalahan yang merugikan manusia itu sendiri, misalnya kebiasaan membakar lahan, hutan dan kebun yang menimbulkan maslah baru yaitu berupa kabut asap. Timbulnya masalah baru berupa kabut asap akan mengganggu salah satunya dari aspek kesehatan seperti Inpeksi Saluran Pernapasan (ISPA).

Kerugian dari masalah tersebut baru dirasakan ketika manusia mulai terganggu. Sehingga diperlukan cara alternatif untuk mencegah atau mengurangi dampak bencana. Misalnya dengan menerapkan kearifan yang dimiliki masyarakat. seperti bahuma batahutn yang dimiliki oleh masyarakat Suku Dayak. Kebakaran lahan, hutan dan kebun di tahun 2015 meningkatkan kesadaran masyarakat untuk peduli terhadap lingkungan. Adanya regulasi dari pemerintah pusat seperti UU No. 32 Tahun 2009 Tentang perlindungan dan pengelolaan lingkungan hidup menjadi salah satu bentuk pelindung lingkungan secara tertulis.

\section{METODOLOGI}

Pendekatan penelitian yang digunakan dalam penelitian ini adalah pendekatan penelitian secara etnografi yang merupakan studi tentang bagaimana individu atau kelompok masyarakat mencipta dan memahami kehidupan sehari-hari (Sutopo, 2006) dengan lokasi penelitian yaitu di Kalimantan Tengah.

\section{HASIL DAN PEMBAHASAN}

\section{Berdasarkan buku Maneser Panatau Tatu Hiang} yang disunting Dra. Nila Riwut Cetakan Ke Dua Tahun 2015 menyebutkan bahwa Suku Dayak adalah suku sebutan yang umum di Kalimantan bahkan di seluruh Indonesia. O.K Rahmat dan R. Sunardi mengatakan dalam Manaser Panatau Tatu Hiang bahwa Dayak adalah satu perkataan untuk menamakan stam-stam yang tidak beragama islam yang mendiami pedalaman Kalimantan.

Amanat para leluhur seperti yang disampaikan Kepala Kampung Suku Dayak yang dijadikan sampel penelitian dan yang tertulis dalam buku Maneser Panatau Tatu Hiang bahwa pesan tersebut berbunyi "Haga Lewun Keton, Petak Danom, Ela Sampai Tempun Petak Nana Sare" yang artinya pelihara kampung halamanmu, jangan sampai terjadi, pemilik tanah harus berladang dipinggiran.

Kearifan lokal yang masih ditemukan di beberapa sampel penelitian yang telah ditentukan baik dengan cara observasi, wawancara, dan dihubungkan dengan beberapa kajian literatur yang membahas tentang Kearifan Suku Dayak, maka diperoleh kearifan lokal yang masih bertahan sampai saat ini diantaranya seperti Bahuma Batahutn.

Bahuma Batahutn yaitu kegiatan perladangan yang dilakukan oleh Suku Dayak yang dilaksanakan dengan acara ritual yang sakral. Kegiatan berladang tersebut hanya panen satu kali dalam setahun. Hal ini tentu akan berdampak positif bagi lingkungan yang dijadikan lahan untuk berladang. Jadi lahan untuk berladang diberikan untuk pulih kembali, baru di tanam kembali. Dalam kegiatan berladang ini dilakukan dengan cara 
berkelompok yang disebut dengan Aleatn Uma (memupuk semangat gontong royong). Langkah yang dilakukan dalam kegiatan tersebut seperti membuat sekat bakar selebar 1-4 meter. Perladangan tersebut dilaksanakan atas izin leluhur dan pembacaan arah angin yang dilakukan oleh orang pintar atau petalla guru.

Bentuk kegiatan Bahuma Batahutn diharapkan mampu menjadi salah satu bentuk penjagaan terhadap lingkungan, sehingga bencana kebakaran lahan, hutan dan kebun seperti tahun 2015 dapat diminimalisir, dan menjauhkan dari risiko kabut asap.

\section{KESIMPULAN}

Kearifan lokal merupakan salah satu alat yang berfungsi untuk menjaga kelestarian lingkungan, misalnya seperti kearifan lokal yang dimiliki oleh masyarakat Suku dayak contohnya Bahuma Batahutn yang terkait tentang pengelolaan lingkungan untuk digarap menjadi lahan pertanian atau lahan perkebunan. Dengan demikian bencana lingkungan dapat diminimalisir dengan baik. Selain kearifan lokal yang ada dan berfungsi sebagai penahan laju kerusakan lingkungan, juga perlu aturan-aturan atau regulasi yang kuat, terutama tentang peraturan daerah yang tegas terhadap aktivitas pengrusakan lingkungan. Sehingga lingkungan dapat dijaga dan terjaga dengan baik.

\section{DAFTAR PUSTAKA}

Abdul, M. 2010, Beberapa Kearifan Lokal Suku Dayak Dalam Pengelolaan sumberdaya Alam. Universitas Brawijaya. Malang

Arief, S. 2010, Kesehatan Lingkungan, Universitas Islam Negeri Syarif Hidayatullah. Jakarta.
Arif, Z. 2014, Dasar-Dasar Ilmu Lingkungan. Salemba Teknika. Jakarta.

Basuki. 2012, Penggunaan Kawasan Hutan untuk Budidaya Non Kehutanan Direktorat Perencanaan Hutan Ditjen Planologi Kehutanan.Kementerian Kehutanan. Jakarta.

Bruce, M., Setiawan, B, \& Dwita, H.R. 2007, Pengelolaan Sumberdaya dan Lingkungan. Gadjah Mada University Press. Yogyakarta.

Dantje, T.S. 2015. Toksikologi Lingkungan. Universitas Samratulangi. Manado.

Departemen Pekerjaan Umum. 2007. UndangUndang Nomor 26 Tahun 2007 Tentang Penataan Ruang. Jakarta.

Hermanto, S. 2011. Makalah Mekanisme Pelepasan Kawasan Hutan dan Pinjam Pakai Kawasan Hutan. Dinas Kehutanan Provinsi Kalimantan Tengah. Palangka Raya.

Hermanto, S. 2012. Makalah peluang Investasi Perkebunan pada Kawasan Hutan. Dinas Kehutanan Provinsi Kalimantan Tengah. Palangka Raya.

Nila, R. 2015. Maneser Panatau Tatu Hiang. NR Publishing. Yogyakarta.

Pumpung, H. 2014. Buku Panduan Pumpung Hai Pakat Dayak dan Napak Tilas Pakat Damai Tumbang Anoi. Palangka Raya.

Rachmat, M. 2009. Pedoman Teknis Pelepasan Kawasan Hutan. Majalah Kehutanan Indonesia Kementerian Kehutanan. Jakarta.

Sutopo. 2006. Metodologi Penelitian Kualitatif. Universitas Sebelas Maret Press. Surakarta.

Undang-Undang Republik Indonesia No. 32 Tahun 2009. Perlindungan dan Pengelolaan Lingkungan Hidup. Kementerian Lingkungan Hidup. Jakarta. 